\title{
Some Soil properties, Growth Parameters and Crop Yield as Responded to Soil Temperature Management
}

\author{
A. A. El-Kharbotly and E. M. Hokam \\ Soils and Water Deptartment Faculty of Agriculture, Suez, \\ Canal University, Ismailia, Egypt.
}

\begin{abstract}
$\mathbf{M}$
ANAGEMENT of soil temperature could be useful for improving plant growth and crop yield. The current study was divided in two separated experiments: columns experiment and the other was field experiment. Both experiments intended to investigate the effects of clay mineral bentonite and soil surface mulching on some soil hydraulic and thermal parameters. In addition to these properties, the study included the effect on plant growth and crop yield of maize (Zea mays L. var TWC 352) and faba bean (Vicia faba L. var Giza 843). The obtained results revealed that, bentonite incorporation resulted in enhancement of soil water retention, especially in the low tension zone, which is more critical for irrigation scheduling. Also, it decreased saturated soil hydraulic conductivity and increased soil thermal conductivity, compared to the non-treated. Moreover, there was a possibility to modify the relative hydraulic conductivity value obtained from Mualem's model. This modification could be helpful to overcome the deep drying front occurred in wetted soil due evaporation. Columns experiment showed that sandy soil was more responding to temperature fluctuations in winter season than that in summer. The lowest values of soil temperature fluctuations among all treatments were recorded under rice straw mulch. The same experiment also showed that, different surface treatments affecting moisture storage in soil, consequently, will affect water saving and energy. Field experiments indicated that, rice straw mulch could be the suitable practice to conserve soil moisture and obtain higher crop yield under both summer and winter conditions. The results also revealed that, the limiting factor for the highest growth and yield of maize was the lowest soil temperature fluctuation, while the limiting factor for the highest growth and yield of beans was the relative increase in soil temperature.
\end{abstract}

Keywords: Soil hydraulic properties, Soil temperature fluctuation, Maize, Faba bean

Sandy soil usually has poor chemical and physical properties. Bentonite deposits are effective amendments for improvement of physicochemical characteristics of Torripsamment soils (Sheta et al., 2006). Croker et al. (2004) also reported that, the use of bentonite on sandy soils is a promising technology to increase biomass production and rehabilitate the exchange properties of these degraded 
soils in the long-term. Abdel-Nasser et al. (2007) found a significant increase in soil water retention parameters such as saturation water content, field capacity, permanent wilting point and available water, as a result of applied natural clay deposits to sand soil. The relatively simple equation introduced by van Genuchten (1980) was used for construction of water content-pressure head curve, $\theta(h)$. Also, this model could be used to derive a closed form analytical expression to predict relative hydraulic conductivity, $K_{r}$, of the same studied soil, based on the model described by Mualem (1976). This application could provide a flexibility to detect the magnitude of $K_{r}$ as affect the drying depth exiting in wetted soil due to moisture depletion/evaporation, as will be suggested in the current investigation.

Surface mulch application present opportunities for utilizing a range of organic or other wastes that may benefit crop and soil-water relations (Lee, 1997 and Parkinson et al., 1999; Movahedi Naeni \& Cook, 2000a and Sellers et al., 2001). Several investigators have reported that, soil thermal regime under particular mulching materials is different from that of bare soil, where soil temperature often being lower under surface mulched with such materials (Bristow, 1988 and Sarkar et al., 2007). Other has documented much increasing soil temperature (Ramakrishna et al., 2006). These conflicting reports may be related to the type and timing of mulch application and soil temperature measurements. Straw mulch resulted in lower soil heat flux during day time and higher soil heat flux during night time compared to the bare soil. Such layer of straw mulch reduced the amplitude of daily temperature variation, while the effect of mulch becomes less pronounced with increasing soil depth (Dahiya et al., 2007; Sarkar et al., 2007 and Sarkar and Singh, 2007). The decrease in temperature amplitude under some mulching materials is due to the influence of such material by insulating the soil surface as describe by Shinners et al. (1993). In addition to the effect of straw mulch on soil temperature, Dahiya et al. (2007) concluded that, due to the evaporation property of the surface placed straw layer, mulching treatment reduced soil water loss compared to that from nonmulched soil during the study period.

Transparent polyethylene mulch is commonly used particularly in arid, semiarid, and frigid regions, for conserving soil temperature and water content, to improve crop growth. The formation of water droplets on the inner surface of the polyethylene film can highly reduce transmissivity of long-wave radiation but does not affect short-wave radiation, which in turn reduces heat convection and evaporation from the soil (Wu et al., 2007). Soil temperature under transparent plastic mulch showed a strong diurnal cycle with the highest temperature at 14:00-16:00 PM and the lowest at 7:00 AM. Moreover, the diurnal variation in soil temperature was $2-6{ }^{\circ} \mathrm{C}$ higher in the transparent plastic mulch than that in bare soil (Li. 2011). Recently Yaghi et al. (2013) also indicated that plastic mulch generally raised soil temperature, whereas transparent plastic mulch raised the limits of the soil temperature by $6.4,5.9$ and $5.6^{\circ} \mathrm{C}$ at soil surface, $5 \mathrm{~cm}$, and 10 $\mathrm{cm}$ soil depth, respectively. Consequently, it is thought that amelioration of upper layer temperature in sandy soil is beneficial for growing economical plants. This

Egypt. J. Soil Sci. 56, No. 1 (2016) 
could be done by trialing to lower its temperature during the hottest days of summer and/or worming up during the coldest days of winter. The current investigation aimed to evaluate the effect of soil surface mulching and incorporation of bentonite on some soil properties, plant growth and crop yield of maize in the summer season and faba bean in the winter season.

\section{Soil preparation}

\section{Material and Methods}

Soil used in the current investigation was a coarse texture soil collected from the Experimental Farm of the Faculty of Agriculture, Suez Canal University, Ismailia, Egypt. Some selected chemical and physical properties are in Table 1. To determine the effect of bentonite incorporation on soil water retention curve, $16 \mathrm{Mg} \mathrm{ha}^{-1}$ of prepared bentonite was incorporated in two rates: mixing in the upper 0.1 and $0.2 \mathrm{~m}$ soil layers. Soil water retention curve was performed using tension table in the low tension zone: 0.0 to $10.0 \mathrm{kPa}\left(0.0\right.$ to $\left.100 \mathrm{~cm} \mathrm{H}_{2} \mathrm{O}\right)$ as described by Klute (1986). In the high tension zone: 10.0 to $1500 \mathrm{kPa}$ (100 to $15000 \mathrm{~cm} \mathrm{H}_{2} \mathrm{O}$ ) a pressure plate extractor was used as described by Carter (1993). Then soil water retention data was fitted to van Genuchten (1980) model and the three independent fitting parameters $(\alpha, n, m)$ obtained from the graphical interpretation were checked using RETC software.

\section{Columns experiment}

The current investigation consisted of two experiments. The first one was a columns experiment, in which total of 18 PVC soil columns were used. Each one was $0.005 \mathrm{~m}$ wall thickness, $0.19 \mathrm{~m}$ in diameter and $0.45 \mathrm{~m}$ in length. The bottom end was sealed with perforated cap. Just above the bottom end, a layer of pre-washed cheesecloth was placed. Each column was packed with $0.40 \mathrm{~m}$ total soil depth, with the same bulk density, at which the soil was found in the field. During successive packing total of 5 temperature sensors (LM35, connected with computer-based data logger) were placed horizontally in holes drilled along the side of each column. The sensors were inserted at 0.01, 0.06, $0.15,0.25$ and $0.35 \mathrm{~m}$ beneath the soil surface. To minimize lateral heat transfer, the columns were insulated with $1 \mathrm{~cm}$ Styrofoam layer covered with aluminum foil sheet. After that, irrigation water from Ismailia canal was added to bring the soil moisture content to its field capacity. Then six treatments have been began: the $1^{\text {st }}$ one deal with covering soil surface by $1.25 \mathrm{~mm}$ thickness transparent polyethylene sheet, TP, where a hole of $1 \mathrm{~cm}$ diameter was made in the center of each TP sheet. The $2^{\text {nd }}$ and $3^{\text {rd }}$ treatments were usage of rice straw applied in two rates, namely: 4 and $8 \mathrm{Mg} \mathrm{ha}^{-1}$ on the soil surface, named $\mathrm{R}_{4}$ and $R_{8}$, respectively. The $4^{\text {th }}$ and $5^{\text {th }}$ treatments were incorporation of $16 \mathrm{Mg} \mathrm{h}^{-1}$ of the prepared bentonite mixed in two ways, namely: in the top 0.1 and $0.2 \mathrm{~m}$ soil layer, named $\mathrm{B}_{10}$ and $\mathrm{B}_{20}$, respectively. The last treatment was bare soil and referred as control. Soil columns were subjected to natural evaporation, where first depletion level was extended until its moisture content reduced by $15 \%$ from soil field capacity, FC. The second and third moisture depletions were $30 \%$ and $45 \%$ from soil FC, afterwards, each specified soil column was dissected into $0.10 \mathrm{~m}$ sections, and soil moisture was determined. This 
described experimental setup was conducted twice, during summer 2012 and winter 2013.

TABLE 1. Some chemical and physical properties of investigated soil.

\begin{tabular}{|c|c|c|c|c|c|c|c|}
\hline \multicolumn{8}{|c|}{ Physical properties } \\
\hline \multicolumn{4}{|c|}{ Particles size distribution } & \multirow{3}{*}{$\begin{array}{c}\text { Texture } \\
\text { Class }\end{array}$} & \multicolumn{2}{|c|}{ Densities } & \multirow{3}{*}{$\begin{array}{c}\begin{array}{c}\text { Total } \\
\text { porosity }\end{array} \\
\%\end{array}$} \\
\hline C. sand & F. sand & Silt & Clay & & Bulk & Particles & \\
\hline \multicolumn{4}{|c|}{$\%$} & & \multicolumn{2}{|c|}{$\mathrm{Mg} \mathrm{m}^{-3}$} & \\
\hline 80.1 & 15.1 & 1.8 & 3.0 & Sand & 1.631 & 2.596 & 37.17 \\
\hline \multicolumn{8}{|c|}{ Chemical properties } \\
\hline \multicolumn{2}{|c|}{$\mathrm{EC}_{\mathrm{e}}$} & \multirow{2}{*}{\multicolumn{2}{|c|}{$\mathrm{pH}$}} & \multicolumn{2}{|c|}{$\mathrm{CaCO}_{3}$} & \multicolumn{2}{|c|}{$\mathrm{OM}$} \\
\hline \multicolumn{2}{|c|}{$\mathrm{dSm}^{-1}$} & & & \multicolumn{4}{|c|}{$\%$} \\
\hline \multicolumn{2}{|c|}{1.5} & \multicolumn{2}{|c|}{7.31} & \multicolumn{2}{|c|}{1.3} & \multicolumn{2}{|c|}{0.14} \\
\hline
\end{tabular}

\section{Field experiment}

Second experiment was conducted on the Experimental Research Farm, Fac. of Agriculture, Suez Canal Uni. Ismailia, Egypt, during two successive seasons, i.e., summer 2012 and winter 2013. The experimental design was complete randomized block design in three replicates. Each experimental unit was a strip of $15 \mathrm{~m}$ long and $0.5 \mathrm{~m}$ width irrigated with a drip lateral. The abovementioned six treatments in columns experiment were also here investigated, in which rice straw mulch was stabilized using fishing net. In summer season, maize grains were planted on May $1^{s t}$, 2012, while, faba bean seeds were planted on November 30, 2012, as winter crop. Normal agricultural practices were conducted according to the Egyptian Ministry of Agriculture. Amount of irrigation water required was calculated based on Penman-Monteith equation (Allen et al., 1998). Drip irrigation system was used, in which lateral lines were $16 \mathrm{~mm}$ in diameter with GR emitter type of $4.0 \mathrm{l} \mathrm{h}^{-1}$ discharge rate under working pressure of $0.1 \mathrm{MPa}$. The uniformity of the irrigation network was checked, and Ismailia canal water was used. After physiological maturity, 10 plants from each experimental unit were randomly harvested to determine some growth parameters and crop yield.

\section{Results and Discussions}

Soil salinity and $\mathrm{pH}$

The air dried bentonite mixture was incorporated in the air dried soil in two different ways ( $i$. e . incorporation with the top 0.1 and $0.2 \mathrm{~m}$ soil layers). As the soil bulk density reached $1.6 \mathrm{Mg} \mathrm{m}^{-3}$ bentonite almost represent about $0.5 \%$ and $1.0 \%$ in the first and the second layers, respectively. After that, soil samples were taken to determine some soil physical and chemical properties, (Table 2). The data listed revealed that, bentonite incorporation in such sandy soil resulted in an increase of soil paste electrical conductivity from 1.5 to 1.83 and $2.20 \mathrm{dS} \mathrm{m}^{-1}$ for 0.5 and $1.0 \%$ rates, respectively. Such increase may attribute to high salt content found in bentonite mixture which has an electrical conductivity of about $16 \mathrm{dS} \mathrm{m}^{-1}$ in its saturated paste extract. Also, there was an increase in soil $\mathrm{pH}$ from 7.31 to 7.98 and 8.29 for 0.5 and $1.0 \%$ rates, respectively. This increase was due to the high $\mathrm{pH}$ of bentonite mixture that was 8.8 measured in 1:10 bentonite: water

Egypt. J. Soil Sci. 56, No. 1 (2016) 
suspension. However, increasing application rate of bentonite resulted in slightly increase in soil EC and $\mathrm{pH}$, but soil was still non-saline non-alkali.

TABLE 2. Effect of bentonite incorporation on some chemical and physical soil properties.

\begin{tabular}{|c|c|c|c|}
\hline Parameters & Soil & $\begin{array}{l}\text { Soil+0.5\% } \\
\text { Bentonite }^{\dagger} \\
\end{array}$ & $\begin{array}{l}\text { Soil+1.0\% } \\
\text { Bentonite }^{\dagger}\end{array}$ \\
\hline \multicolumn{4}{|c|}{ Chemical parameters } \\
\hline $\mathrm{ECe}\left(\mathrm{dSm}^{-1}\right)$ & 1.50 & 1.83 & 2.20 \\
\hline $\mathrm{pH}$ & 7.31 & 7.98 & 8.29 \\
\hline \multicolumn{4}{|l|}{ Soluble cations $\left(\mathrm{mmol}_{\mathrm{c}} \mathrm{l}^{-1}\right)$} \\
\hline $\mathrm{Ca}^{++}$ & 7.56 & 8.00 & 8.89 \\
\hline $\mathrm{Mg}^{++}$ & 4.84 & 5.24 & 7.02 \\
\hline $\mathrm{K}^{+}$ & 0.47 & 0.76 & 0.92 \\
\hline $\mathrm{Na}^{+}$ & 2.60 & 4.30 & 5.17 \\
\hline \multicolumn{4}{|l|}{ Soluble anions $\left(\mathrm{mmol}_{\mathrm{c}} \mathrm{l}^{-1}\right)$} \\
\hline $\mathrm{CO}_{3}^{--}$ & 0.00 & 0.00 & 0.00 \\
\hline $\mathrm{HCO}_{3}^{-}$ & 3.11 & 3.70 & 4.45 \\
\hline $\mathrm{Cl}^{-}$ & 6.34 & 7.40 & 8.89 \\
\hline $\mathrm{SO}_{4}^{--}$ & 6.05 & 7.20 & 8.66 \\
\hline SAR & 1.04 & 1.34 & 1.50 \\
\hline \multicolumn{4}{|c|}{ Physical parameters } \\
\hline Bulk density $\left(\mathrm{Mg} \mathrm{m}^{-3}\right)$ & 1.631 & 1.639 & 1.647 \\
\hline Particles density $\left(\mathrm{Mg} \mathrm{m}^{-3}\right)$ & 2.596 & 2.568 & 2.567 \\
\hline Air dry water content $\left(\mathrm{kg} \mathrm{kg}^{-1}\right)$ & 0.0035 & 0.0040 & 0.0045 \\
\hline Saturation percentage $\left(\mathrm{kg} \mathrm{kg}^{-1}\right)$ & 0.1880 & 0.1970 & 0.2060 \\
\hline \multicolumn{4}{|l|}{ Hydraulic parameters } \\
\hline $\mathrm{K}_{\mathrm{S}}\left(\mathrm{cm} \mathrm{hr}^{-1}\right)$ & 30.16 & 29.12 & 27.60 \\
\hline$\theta_{\mathrm{S}}\left(\mathrm{cm}^{3} \mathrm{~cm}^{-3}\right)$ & 0.3066 & 0.3229 & 0.3393 \\
\hline$\theta_{\mathrm{r}}\left(\mathrm{cm}^{3} \mathrm{~cm}^{-3}\right)$ & 0.0189 & 0.0195 & 0.0208 \\
\hline$\alpha\left(\mathrm{cm}^{-1}\right)$ & 0.02289 & 0.02223 & 0.02152 \\
\hline $\mathrm{n}$ & 2.66040 & 2.67104 & 2.72891 \\
\hline $\mathrm{m}$ & 0.62411 & 0.62561 & 0.63355 \\
\hline $\mathrm{R}^{2}$ & 0.9798 & 0.9582 & 0.9695 \\
\hline \multicolumn{4}{|l|}{ Thermal parameters } \\
\hline Specific heat $\left(\mathrm{cal} \mathrm{g}^{-1}\right)$ & 0.2016 & 0.2016 & 0.2017 \\
\hline Volumetric heat Capacity $\left(\mathrm{cal} \mathrm{cm}^{-3}\right)$ & 0.3288 & 0.3304 & 0.3322 \\
\hline Thermal Diffusivity $\left(\mathrm{cm}^{2} \mathrm{~s}^{-1}\right)$ & $2.099 \times 10^{-3}$ & $2.430 \times 10^{-3}$ & $2.737 \times 10^{-3}$ \\
\hline Thermal conductivity $\left(\mathrm{cal} \mathrm{cm}^{-1} \mathrm{~s}^{-1{ }^{\circ}} \mathrm{C}^{-1}\right.$ ) & $0.69015 \times 10^{-3}$ & $0.80287 \times 10^{-3}$ & $0.90923 \times 10^{-3}$ \\
\hline
\end{tabular}

Egypt. J. Soil Sci. 56, No.1 (2016) 
${ }^{\dagger}$ Mixture of 1:1 sodium and calcium bentonite

\section{Hydraulic properties}

Regarding to the ability of soil to retain water, the closed-form expression of van Genuchten (1980) was considered as a simple model to reconstruct soil water retention curve (laid from 1 to $15000 \mathrm{~cm} \mathrm{H}_{2} \mathrm{O}$ ) for original soil, soil+0.5\% and soil $+1.0 \%$ bentonite (Fig. 1A). Curves showed that, the effect of bentonite incorporation on sandy soil water retention was pronounced in the low tension zone, from 1 to $100 \mathrm{~cm} \mathrm{H}_{2} \mathrm{O}$ (a critical range for irrigation scheduling). Therefore, bentonite application increased soil field capacity from 0.148 to 0.161 for original soil and soil $+1.0 \%$ bentonite, respectively. Saturated soil hydraulic conductivity, $K_{s}$, was also slightly changed. It reduced from 30.16 to $27.60 \mathrm{~cm} \mathrm{~h}^{-1}$ for original soil and soil $+1.0 \%$ bentonite, respectively. However, soil $K s$ was still classified as rapid. It is expected that, such soil properties will be more affected when bentonite excessed $1.0 \%$. As the pressure head increased the three curves were almost overlapped with each other indicating very little changes in the $\theta(h)$ function. However, van Genuchten's model of soil water content as a function of the pressure head could be gave by:

$$
\theta=\theta_{\mathrm{r}}+\frac{\left(\theta_{\mathrm{s}}-\theta_{\mathrm{r}}\right)}{\left[1+(\alpha h)^{\mathrm{n}}\right]^{\mathrm{m}}}
$$

where $\theta_{\mathrm{r}}, \theta_{\mathrm{S}}$, represented the residual and saturated soil moisture contents, respectively, $\alpha, n$ and $\mathrm{m}$, are independent parameters which have to be estimated from the experimentally soil water retention data (assuming $m=1-1 / n$ ). The values of $R^{2}$ for both experimental and estimated data were $0.9798,0.9582$ and 0.9695 for original soil, soil $+0.5 \%$ and soil $+1.0 \%$ bentonite, respectively. Results of the $\theta_{\mathrm{r}}, \theta_{\mathrm{S}}, \alpha, n$ and $m$ parameters presented in Table 2 were in concomitant with that listed by Carsel \& Parrish (1988) and Abdel-Nasser et al. (2007). More efficient representation and comparison of the hydraulic properties of different treated soils, in addition to easily characterizing of spatial variability of soil hydraulic properties could also be provide by Eq. 1. This model could be combined with that produced by Mualem (1979) to predict the relative hydraulic conductivity $(K r)$ :

$$
\mathrm{K}_{\mathrm{r}}=\Theta^{1 / 2}\left[\int_{0}^{\Theta} \frac{1}{\mathrm{~h}(\mathrm{x})} \mathrm{dx} / \int_{0}^{1} \frac{1}{\mathrm{~h}(\mathrm{x})} \mathrm{dx}\right]^{2}
$$

where $\mathrm{h}$ is the pressure head, and given here as a function of the dimensionless water content:

$$
\Theta=\frac{\theta-\theta_{\mathrm{r}}}{\theta_{\mathrm{s}}-\theta_{\mathrm{r}}}
$$

To solve Eq. 3, an expression relating the dimensionless water content to the pressure head was needed. Therefore, the parameters $\alpha, n$, and $m$ estimated from obtained soil water retention data could be integrated in Eq. 2, then the relative

Egypt. J. Soil Sci. 56, No. 1 (2016) 
hydraulic conductivity can be expressed in terms of pressure head $\mathrm{h}$ using the following equation:

$$
K_{r}(h)=\frac{\left[1-(\alpha h)^{n-1}\left[1+(\alpha h)^{n}\right]^{-m}\right]^{2}}{\left[1+(\alpha h)^{n}\right]^{m / 2}}
$$

A

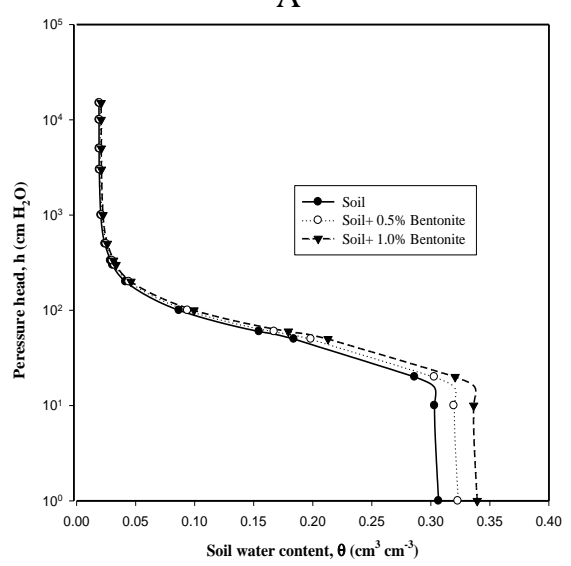

B

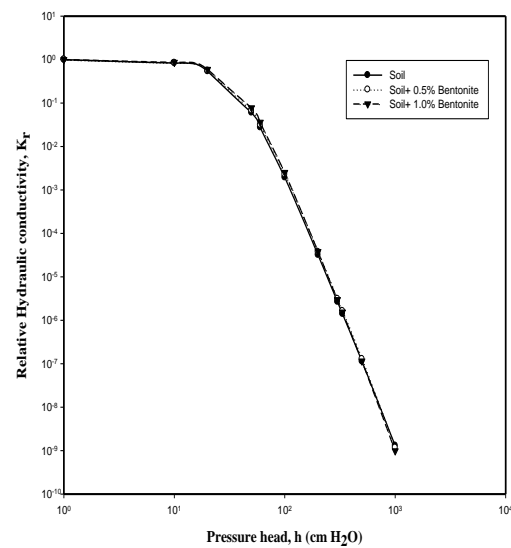

Fig. 1. Soil hydraulic properties: A) soil water retention curve; B) relative hydraulic conductivity.

The results of $K_{r}(h)$ for original soil, soil $+0.5 \%$ and soil $+1.0 \%$ bentonite are presented in Fig. 1B. As can be seen, $K_{r}$ value starts out with almost zero slopes at pressure head values closed zero, then falls off rapidly as $h$ increased. Fig. 1B also showed that, when pressure head reached $100 \mathrm{~cm} \mathrm{H}_{2} \mathrm{O}$ the $K_{r}$ value reached $10^{-3}$, and fallen off rapidly to reach $10^{-9}$ at pressure head $10^{3} \mathrm{~cm} \mathrm{H}_{2} \mathrm{O}$. Payne (1987) also showed that at moisture contents below $0.05 \mathrm{~m}^{3} \mathrm{~m}^{-3}, K$ of sandy soils is negligible. This value of soil moisture content was reached at pressure head close to $200 \mathrm{~cm} \mathrm{H}_{2} \mathrm{O}$ where $K_{r}$ reached $10^{-5}$. It was appeared that, bentonite has nearly no effect on $K_{r}$, as the obtained curves were almost overlapped with each other. These results may be attributed to that; $K_{r}$ estimated from Eq. 4 means that each $K_{\theta}$ was divided by $K_{s}$ for the same treated soil. To overcome this defect, it is suggested here to divide $K_{\theta}$ value of each treatment by $K_{s}$ value of the original soil (instead of $K_{s}$ for the same treated soil), so it will resulted in different $K_{\theta}$ values. These different values could be beneficial to detect how to reduce the drying front zone that built up due to evaporation process occurred in wetted soil.

\section{Thermal properties}

Soil thermal properties are considered as volumetric heat capacity $C$, soil thermal conductivity $\kappa$, and soil thermal diffusivity $D_{T}$. These parameters measure soil ability to store heat, conduct heat, and the thermal inertia of soil, respectively. The data obtained of these parameters of studied soils are presented in Table 2. Application of bentonite to soil resulted in small increase 
in soil thermal conductivity. Early, Van Rooyen and Winterkorn (1959) stated that, adding small amounts of clay particles to cohesion less granular material acts as binder and improve thermal conductivity. Farouki (1966) concluded that, the effective thermal conductivity of sandy soil was improved considerably by clay application, in spite of the much lower thermal conductivity of clay particles compared with quartz grains. The clay particles were thought to improve the interfacial conduction characteristics, especially in the nearly dry state. Together with its associated water films, clay particles provided good thermal bridges amongst the granular skeleton of sandy soils. The obtained values were in close agreement with that listed by Geiger et al. (1995) and AbuHamdeh (2003) for sandy soils. The results showed that, there is almost no effect of bentonite on soil heat capacity. This may attributed to that, the heat capacity of bentonite was found to be very close to that of the soil.

\section{Evaporation from moist soil}

To evaluate the effect of investigated treatments on water evaporation from soil, cumulative evaporation from soil columns, in $\mathrm{g}$ water per soil column was calculated. For both summer and winter conditions, curves in Fig. 2 revealed that, the cumulative evaporation from $\mathrm{B}_{10}, \mathrm{~B}_{20}$, and $\mathrm{C}$ treatments were almost similar, and much more than that occurred under $\mathrm{TP}, \mathrm{R}_{8}$, and $\mathrm{R}_{4}$. These findings showed that TP and $\mathrm{R}_{8}$ recorded the lowest evaporation at the same elapsed time. $\mathrm{R}_{4}$ treatment came in a middle position among the treatments. To obtain similar cumulative evaporation for $45 \%$ depletion, treatments $\mathrm{B}_{10}, \mathrm{~B}_{20}$, and $\mathrm{C}$ took 14 days to evaporate 767,756 , and $741 \mathrm{~g}$ water, respectively, under summer conditions. While $\mathrm{R}_{4}$ required 18 days to evaporate $724 \mathrm{~g}$ water, TP and $R_{8}$ needed 20 days to evaporate 729 and $725 \mathrm{~g}$ water, respectively. These observations could be helpful in the irrigation scheduling, where irrigation frequency or its amounts may be reduced, particularly under $\mathrm{R}_{8}$ which is more recommended under summer condition. In the same context, Sarkar et al. (2007) reported that, straw mulch forms a barrier to evaporating soil surface and alters micro-climate which acts as driving force for evaporation. For bentonite treatments, Sheta et al. (2006) reported that, bentonite application alters water evaporation from soil when its application rate exceeds $5 \%$. In the current study the highest application rate was $1 \%$.
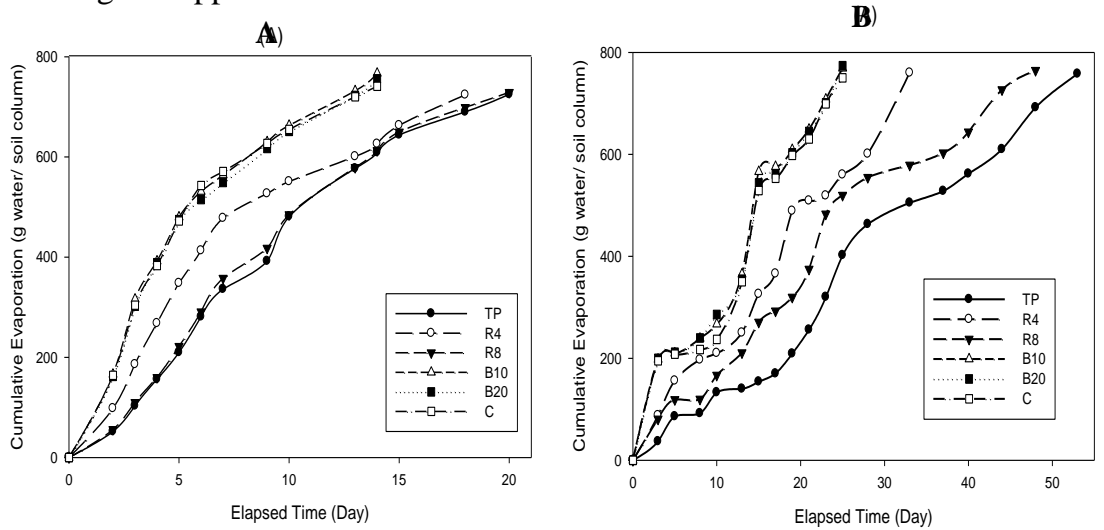

Egypt. J. Soil Sci. 56, No. 1 (2016) 
Fig. 2. Effect of different soil surface treatments on cumulative evaporation, $g$ water per soil column, under both $A$ ) summer and $B$ ) winter conditions.

Soil moisture distributions along the soil column were determined at the three investigated depletion levels. For both summer and winter, obtained results were plotted in Fig. 3 and 4 for 15, 30, and 45\% depletion levels, respectively. The Fig. showed that, all treatments exhibited very similar moisture distribution patterns at $15 \%$ and $45 \%$ depletion levels. However, at the intermediate depletion level, $30 \%$, and especially for the upper soil sections, TP treatment recorded the highest soil moisture content followed by $R_{4}$ and $R_{8}$. On the other hand, treatments $\mathrm{B}_{10}, \mathrm{~B}_{20}$, and $\mathrm{C}$ recorded the lowest soil moisture contents as it approaches air dry conditions at soil surface. The reason for these findings may be the slow evaporation rates obtained for $\mathrm{TP}, \mathrm{R}_{8}$, and $\mathrm{R}_{4}$ which allow more time for soil moisture redistributions along the soil columns.

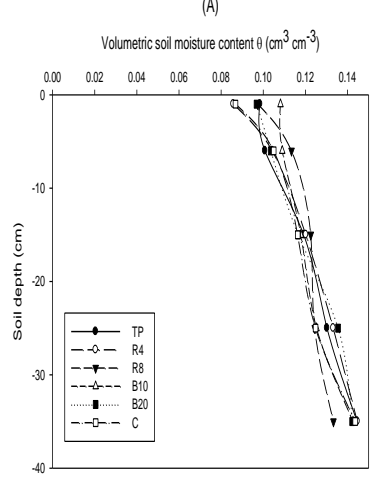

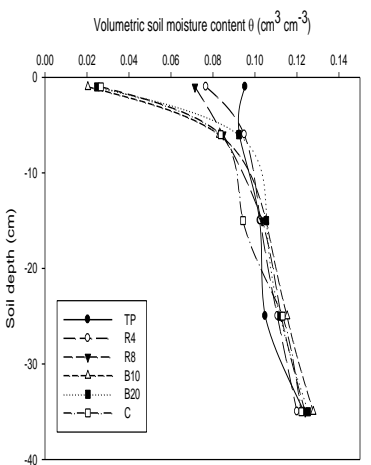

(C)

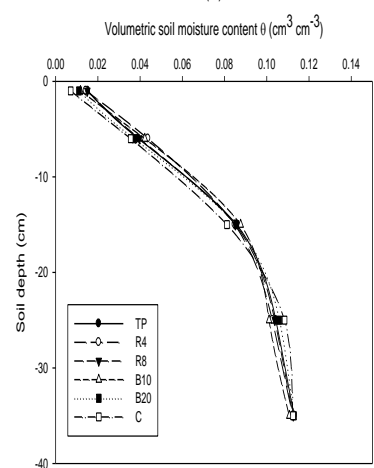

Fig. 3. Effect of soil surface treatments on soil moisture distribution at the different depletion levels: (A) $15 \%$; (B) $30 \%$; and (C) $45 \%$ from soil field capacity, for Ismailia sandy soil during summer, 2012.

(A)

Volumetric soil moisture content $\theta\left(\mathrm{cm}^{3} \mathrm{~cm}^{-3}\right.$

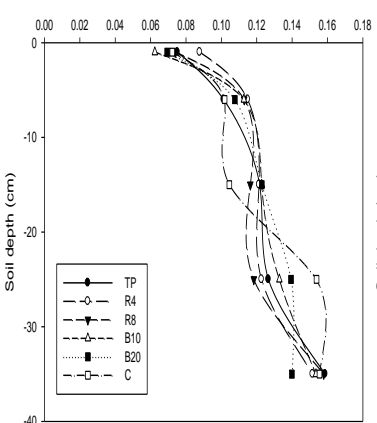

(B)

Volumetric soil moisture content $\theta\left(\mathrm{cm}^{3} \mathrm{~cm}^{-3}\right)$

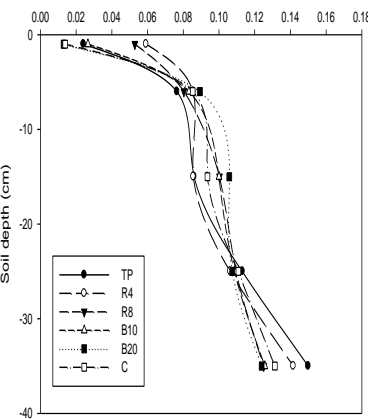

(C)

Volumetric soil moisture content $\theta\left(\mathrm{cm}^{3} \mathrm{~cm}^{-3}\right)$

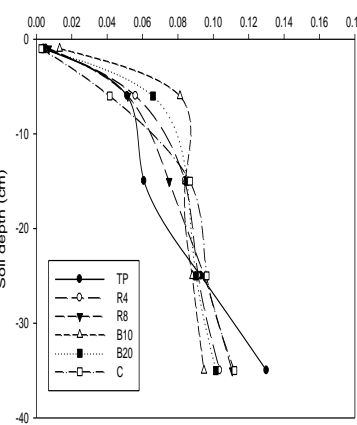

Fig. 4. Effect of soil surface treatments on soil moisture distribution at the different depletion levels: (A) 15\%; (B) 30\%; and (C) $45 \%$ from soil field capacity, for Ismailia sandy soil during winter 2012. 
Figures 3 and 4 indicate that the drying front increased and deepen as moisture depletion increased. However, it is natural under field conditions that moisture depletion continues and reached $70 \%$. In this case, we expect that drying front become deeper, and covered the root zone. This requires an increase of non-saturated hydraulic conductivity value to provide a suitable water supply and compensate moisture deficit. Under winter condition, nearly all investigated treatments appeared a same manner of cumulative evaporation and soil moisture distribution, as well as fund under summer conditions. $\mathbf{R}_{4}$ treatment required 33 days to evaporate $760 \mathrm{~g}$ water While $\mathrm{R}_{8}$ needed $4_{8}$ days to evaporate $765 \mathrm{~g}$ water. The longest period of 53 days was taken by TP to evaporate $758 \mathrm{~g}$ water. Figure 4 showed that, at $30 \%$ depletion level both $\mathrm{R}_{4}$ and $\mathrm{R}_{8}$ recorded higher values of soil moisture contents at the soil surface, while all treatments recorded low values at $45 \%$ depletion level. For both 30 and $45 \%$ depletion levels, TP treatment recorded higher soil moisture content in the middle and lower sections of soil column.

\section{Soil temperature fluctuation}

Soil temperature is directly affected by incoming solar radiation, so, any surface practice changed the amount and/or intensity of solar radiation reaching soil surface will change soil temperature. Much solar radiation energy reached soil surface usually used for evaporation, consequently, evaporation will cools soil. One aim of the current experiment was to evaluate the effect of soil surface mulch, in addition to bentonite incorporation on soil temperature fluctuation. Obtained results showed that, for all treatments, the greatest fluctuations in soil temperature were found in the uppermost $20 \mathrm{~cm}$ soil layer. After this depth, soil temperature was damped and its time was lagged. Table 3 showed that, under summer conditions, the lowest weighted average of soil temperature amplitudes for the upper $20 \mathrm{~cm}$ soil layer, $\mathrm{T}_{\text {wa20 }}$, were recorded under straw mulch treatments (5.94 and $5.91 \mathrm{C}^{\circ}$ for $\mathrm{R}_{4}$ and $\mathrm{R}_{8}$, respectively). Also, the lowest weighted average of max. soil temperature, $\mathrm{T}_{\text {wa } \max }$, was recorded under the same treatments. On the other hand, $i . e$. under winter condition, the lowest values of $\mathrm{T}_{\text {wa } \max }$ was recorded under bentonite treatments ( 20.7 and $20.6 \mathrm{C}^{\circ}$ for $\mathrm{B}_{10}$ and $\mathrm{B}_{20}$, respectively), while the lowest values of $\mathrm{T}_{\text {wa20 }}$ were recorded under straw mulch. For both seasons, the highest values of $\mathrm{T}_{\text {wa max }}$ were recorded under TP treatment, so, this treatment was exclusive from summer field experiment.

TABLE 3. Weighted average max. temperature of soil column $\left(T_{w a} \max , C^{0}\right)$ and weighted average soil temperature fluctuation of the upper $20 \mathrm{~cm}$ soil layer $\left(\mathbf{T}_{\mathrm{wa20}}, \mathbf{C}^{0}\right)$, estimated for whole soil field capacity.

\begin{tabular}{|c|c|c|c|c|c|c|}
\hline \multicolumn{7}{|c|}{ Treatments: Summer season } \\
\hline & $\mathrm{TP}$ & $\mathrm{R}_{4}$ & $\mathrm{R}_{8}$ & $\mathrm{~B}_{10}$ & $\mathrm{~B}_{20}$ & Control \\
\hline $\mathrm{T}_{\mathrm{wa20}}$ & 14.30 & 5.94 & 5.91 & 7.01 & 7.50 & 7.85 \\
\hline $\mathrm{T}_{\text {wa } \max }$ & 43.2 & 38.1 & 37.3 & 39.2 & 39 & 38.1 \\
\hline \multicolumn{7}{|c|}{ Winter season } \\
\hline $\mathrm{T}_{\mathrm{wa} 20}$ & 9.45 & 7.70 & 5.32 & 8.15 & 8.12 & 8.03 \\
\hline $\mathrm{T}_{\text {wa max }}$ & 26.5 & 22.0 & 23.7 & 20.7 & 20.6 & 24.7 \\
\hline
\end{tabular}

Egypt. J. Soil Sci. 56, No. 1 (2016) 


\section{Summer field experiment}

Soil temperature and moisture

It is important to detect the effect of soil moisture on its temperature changes for the different treatments under the same climatic and irrigation conditions. Soil temperature was measured directly before irrigation at 9:00 AM and on the next day of irrigation at 5:00 PM. These measurements were conducted two times weekly. Obtained data showed that, the values of soil temperatures measured at 9:00 AM were lower than that measured at 5:00 PM on the next day of irrigation. The highest recorded value was $34.2{ }^{\circ} \mathrm{C}$ for $\mathrm{C}$ treatment before irrigation on August, 2012 while the lowest value was $28.7^{\circ} \mathrm{C}$ for $\mathrm{R}_{8}$ recorded on May, 2012. For soil temperatures recorded on next day of irrigation at 5:00 $\mathrm{PM}$, the highest value was $37.2{ }^{\circ} \mathrm{C}$ for $\mathrm{C}$ treatment on June, 2012, while the lowest value was $30.6{ }^{\circ} \mathrm{C}$ for $\mathrm{R}_{8}$ treatment on May, 2012. The differences between $B_{10}, B_{20}$, and $C$ were very small at 9:00 AM before irrigation, but they were noticeable at 5:00 PM on the next day of irrigation. However, $\mathrm{C}$ treatment recorded higher soil temperature than that for both $\mathrm{B}_{10}$ and $\mathrm{B}_{20}$. All treatments enhanced soil moisture storage compared to the control. The most efficient practice was $\mathrm{R}_{8}$, which gave the higher soil moisture content before irrigation, $0.0259 \mathrm{~cm}^{3} \mathrm{~cm}^{-3}$, compared to $\mathrm{C}$ which recorded $0.0170 \mathrm{~cm}^{3} \mathrm{~cm}^{-3}$. After irrigation, $B_{10}, B_{20}$, and $C$ were nearly similar in their moisture contents: 0.102 , 0.103 , and $0.101 \mathrm{~cm}^{3} \mathrm{~cm}^{-3}$, respectively. On the other hand, the $R_{4}$ and $R_{8}$ recorded much more soil moisture contents and their values reached 0.1119 and $0.1399 \mathrm{~cm}^{3} \mathrm{~cm}^{-3}$, respectively. At the middle time of growing season (i.e. on July, 2, 2012) soil temperature was measured at $15 \mathrm{~cm}$ soil depth every hour from sunrise to sunset. Digital soil thermometer $\left( \pm 0.1{ }^{\circ} \mathrm{C}\right)$ was used for such measurements. Air temperature at the height of the plant canopy was also measured every hour, and the obtained results are plotted in Figure 5A, B. The data showed that, maximum soil temperatures recorded under summer conditions, were $33.1,31.6,35.5,36.5$, and $36.8{ }^{\circ} \mathrm{C}$ for $\mathrm{R}_{4}, \mathrm{R}_{8}, \mathrm{~B}_{10}, \mathrm{~B}_{20}$, and $\mathrm{C}$ treatments, respectively. On the other hand, minimum soil temperatures were $26.2,27.1,25.3,25.3$, and $25.9{ }^{\circ} \mathrm{C}$, respectively. So, soil temperature fluctuation were $6.9,4.6,10.1,11.2$, and $10.9^{\circ} \mathrm{C}$ for the same treatments, respectively. It was found that, the highest soil temperature fluctuation was obtained under $\mathrm{B}_{20}$ and $C$ treatments, while the lowest value was obtained under $R_{8}$ treatment. This result had a similar trend found in columns experiment. Air temperatures for that day were 42.5 and $20.5{ }^{\circ} \mathrm{C}$ for maximum and minimum values, respectively, with fluctuation of $22.0^{\circ} \mathrm{C}$. Under $\mathrm{C}$ and $\mathrm{B}_{20}$, soil temperature was close to $37{ }^{\circ} \mathrm{C}$, such temperature was expected to have negative effect on root growth and function, consequently, less production. On the other hand, temperature values recorded under $\mathrm{R}_{8}$ may lead to high plant growth with high yield. Under winter conditions, results showed that, maximum soil temperatures were $27.4,22.4,23.4,21.2,21.0$, and $21.4{ }^{\circ} \mathrm{C}$ for $\mathrm{TP}, \mathrm{R}_{4}, \mathrm{R}_{8}, \mathrm{~B}_{10}, \mathrm{~B}_{20}$, and $\mathrm{C}$, respectively. The minimum soil temperatures were $19.5,15.1,19.2,13.6,13.5$, and $14.1{ }^{\circ} \mathrm{C}$ with temperature fluctuations of $7.9,7.3,4.2,7.6,7.5$, and $7.2{ }^{\circ} \mathrm{C}$ for the same treatments, respectively. For both seasons, results came in agree with that obtained from columns experiment. 

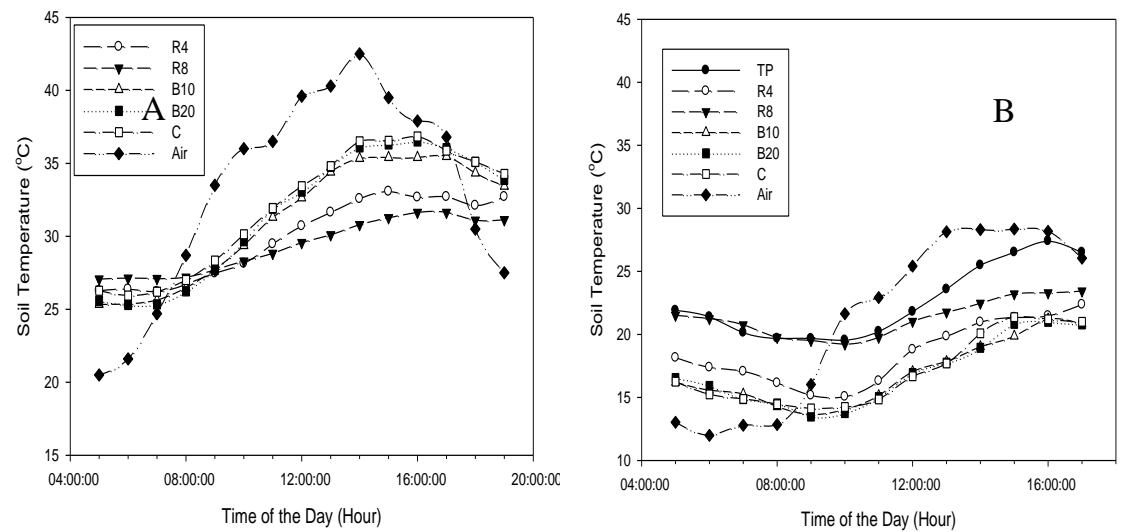

Fig. 5. Soil temperatures at $15 \mathrm{~cm}$ depth under different treatments: A) for maize as summer crop and B) faba bean as winter crop, measured from sunrise to sunset.

\section{Growth parameters and crop yield}

At the end of growing season, 10 maize plants from each replicate were taken to determine some growth and yield parameters. Table 4 showed that, all investigated parameters under $\mathrm{C}$ treatment recorded the lowest values, while, $\mathrm{R}_{8}$ treatment recorded the highest and were significantly different from the other. In regard to the grain yield, all treatments gave a higher yield compared to control, and the percent of yield increases were $38.9,64.1,19.1$, and $13.81 \%$ for $\mathrm{R}_{4}, \mathrm{R}_{8}, \mathrm{~B}_{10}$, and $\mathrm{B}_{20}$, respectively. When considering the effects of the current treatments on soil moisture and temperature, straw mulching found to conserve soil moisture by reducing evaporation amount. This means more availability of water to plants. In general, mulch management, and straw mulch particularly, helped in conservation of soil moisture in the root zone, which ultimately influenced grain yield. In other words, high moisture content increased root proliferation and thus enhanced availability of nutrients to crop roots (Sharma et al., 1997; Sarkar \& Rana, 1999 and Sarkar, 2005). This was well reflected in terms of grain yield. Lal (1974) attributed reduced soil water depletion to the effect of mulch on capillary continuity and thermal conductivity. On the other hand, $\mathrm{C}$ treatment caused soil temperature to rise nearly to $37^{\circ} \mathrm{C}$ for about five hours daily. Such higher temperature may be harmful to maize roots as pointed out by Klepper (1987). Similar results for maize plants under Ismailia conditions were reported by Ali (2011). In general, the previous data indicated that $R_{4}$ and $R_{8}$ are considered as suitable practices to obtain high yield from summer crops compared to the bare soil. That because of avoiding the harmful effect resulted from high soil temperature, additionally to its effect in enhancing soil moisture storage. In comparison to the other treatments, using rice straw mulch, in $8 \mathrm{Mg} \mathrm{ha}^{-1}$, provided a good crop yield. Such findings agreed with the results obtained for soil moisture and temperature recorded under rice straw

Egypt. J. Soil Sci. 56, No. 1 (2016) 
mulch of columns experiment. Wicks et al. (1994) concluded that early maize growth was retarded by increasing mulch levels due to reduced soil temperature, but after tasselling maize grew taller under greater mulch levels due to increased soil moisture. They also reported that both Stover dray matter (DM) and total DM (hence plant height) increased with increasing mulch levels.

TABLE 4. Some growth and yield parameters of maize plants grown under different

\begin{tabular}{|c|c|c|c|c|c|c|c|c|}
\hline Treatment & $\begin{array}{c}\text { Plant } \\
\text { height } \\
(\mathbf{c m})\end{array}$ & $\begin{array}{c}\text { Stover } \\
\text { weight } \\
\left.\text { (g plant }^{-1}\right)\end{array}$ & $\begin{array}{c}\text { Ear weight } \\
\left(\text { g plant }^{-1}\right)\end{array}$ & $\begin{array}{c}\text { Grain } \\
\text { weight } \\
\left.\text { (g plant }^{-1}\right)\end{array}$ & $\begin{array}{c}\text { Ear } \\
\text { radius } \\
(\mathbf{c m})\end{array}$ & $\begin{array}{l}\text { Ear } \\
\text { length } \\
(\mathbf{c m})\end{array}$ & $\begin{array}{c}100 \text { grain } \\
\text { weight } \\
\text { (g) }\end{array}$ & $\begin{array}{c}\text { Grain } \\
\text { yield } \\
\left(\mathrm{kg} \mathrm{ha}^{-1}\right)\end{array}$ \\
\hline $\bar{C}$ & $178.33 \mathrm{~d}$ & $178.33 \mathrm{~d}$ & $187.33 \mathrm{e}$ & $144.61 \mathrm{~d}$ & $4.36 \mathrm{~d}$ & $17.50 \mathrm{c}$ & $27.61 \mathrm{~d}$ & $5842.51 \mathrm{~d}$ \\
\hline $\mathrm{R}_{4}$ & $200.00 \mathrm{~b}$ & $272.00 \mathrm{~b}$ & $237.85 \mathrm{~b}$ & $200.91 \mathrm{~b}$ & $4.60 \mathrm{~b}$ & $18.66 \mathrm{~b}$ & $31.07 \mathrm{~b}$ & $8117.03 \mathrm{~b}$ \\
\hline $\mathrm{R}_{8}$ & $208.00 \mathrm{a}$ & $327.66 \mathrm{a}$ & $290.55 \mathrm{a}$ & $237.33 \mathrm{a}$ & $4.80 \mathrm{a}$ & $20.70 \mathrm{a}$ & $33.77 \mathrm{a}$ & $9588.26 \mathrm{a}$ \\
\hline $\mathrm{B}_{10}$ & $189.00 \mathrm{c}$ & $220.00 \mathrm{c}$ & $219.53 \mathrm{c}$ & $172.28 \mathrm{c}$ & $4.50 \mathrm{c}$ & $18.10 \mathrm{bc}$ & $29.50 \mathrm{c}$ & $6960.24 \mathrm{c}$ \\
\hline $\mathrm{B}_{20}$ & $185.33 \mathrm{c}$ & $210.66 \mathrm{c}$ & $205.93 \mathrm{~d}$ & $164.58 \mathrm{c}$ & $4.40 \mathrm{~d}$ & $18.00 \mathrm{c}$ & $28.66 \mathrm{c}$ & $6649.16 \mathrm{c}$ \\
\hline LSD & 4.57 & 23.60 & 10.09 & 11.97 & 0.09 & 0.60 & 0.99 & 483.45 \\
\hline
\end{tabular}

Values are the means of 10 plants per replicate (from 3 replicate). Values followed by the same letter within a column are not significantly different at the $0.05 \%$ level of probability according to LSD test.

\section{Winter field experiment}

Soil temperature and moisture

Soil temperature was measured directly before irrigation at 9:00 AM and on the next day of irrigation at 5:00 PM twice weekly. The data indicated that, the lowest soil temperature in both before and after irrigation were recorded in January, 2013. For both measurement times, TP treatment recorded the highest soil temperature. In several occasions the differences between $R_{8}$ and $R_{4}$ and between $\mathrm{B}_{10}$ and $\mathrm{B}_{20}$ was very small. The volumetric soil moisture contents before and after irrigation indicated that, plastic mulch resulted in more soil moisture content before irrigation compared with the other treatments. It was followed by $B_{10}$ treatment, while $B_{20}, R_{4}$, and $R_{8}$ were nearly equaled to each other, but still more than the control. The situation after irrigation was changed dramatically, where TP recorded the lowest soil moisture content followed by the control, then $\mathrm{B}_{20}, \mathrm{~B}_{10}, \mathrm{R}_{4}$, and $\mathrm{R}_{8}$. So, the $\mathrm{R}_{8}$ recorded the highest soil moisture contents after irrigation, and its value equaled $0.1641 \mathrm{~cm}^{3} \mathrm{~cm}^{-3}$, i.e., more than field capacity.

\section{Growth parameters and crop yield}

At the end of the growing season, 10 bean plants were taken from each experimental unit to determine some yield and growth parameters. The obtained results were presented in Table 5, and showed that, TP treatment recorded the highest values for all investigated parameters, and was significantly different from other treatments, and followed by $\mathrm{R}_{8}$. The two bentonite treatments were not different significantly from each other in many studied parameters, and still 
significantly higher than the control. The R4 treatment came in middle position between R8 and bentonite treatments. The most important parameter investigated was the seed yield, and obtained values were 7571.36, 5133.49, 6656.43, 4340.84, 4009.96, and $2344.14 \mathrm{~kg} \mathrm{ha}^{-1}$ for TP, $\mathrm{R}_{4}, \mathrm{R}_{8}, \mathrm{~B}_{10}, \mathrm{~B}_{20}$, and $\mathrm{C}$, respectively. Their corresponding increasing percent compared to the control were 222.99, 118.99, $183.96,85.18$, and $71.06 \%$ for $\mathrm{TP}, \mathrm{R}_{4}, \mathrm{R}_{8}, \mathrm{~B}_{10}$, and $\mathrm{B}_{20}$, respectively. Such high values which exceeds the double in TP treatment could be attributed to that, this high temperature (i.e., $27.4{ }^{\circ} \mathrm{C}$ ) was almost in the middle position between the values of $12-32{ }^{\circ} \mathrm{C}$ reported by Klepper (1987) for root growth of bean. In other words, the response of bean to the investigated treatments was much higher than that found for maize crop. These findings could be attributed to botanical and physiological differences between the two crop plants.

TABLE 5. Some growth and yield parameters of bean plants grown under different treatments on Ismailia sandy soil during the winter of 2013.

\begin{tabular}{l|c|c|c|c|c|c}
\hline \multicolumn{1}{c}{ Treatment } & $\begin{array}{c}\text { Dry } \\
\text { weight } \\
\left(\mathbf{g ~ p l a n t ~}^{-1}\right)\end{array}$ & $\begin{array}{c}\text { Plant } \\
\text { height } \\
(\mathbf{c m})\end{array}$ & $\begin{array}{c}\text { No. of } \\
\text { bods }\end{array}$ & $\begin{array}{c}\text { Seeds dry } \\
\text { weight } \\
\left(\mathbf{g ~ p l a n t}^{-1}\right)\end{array}$ & $\begin{array}{c}\mathbf{1 0 0 ~ s e e d ~} \\
\text { weight } \\
(\mathbf{g})\end{array}$ & $\begin{array}{c}\text { Seed yield } \\
\left(\mathbf{k g ~ h a}^{-1}\right)\end{array}$ \\
\hline $\mathrm{C}$ & $46.17 \mathrm{e}$ & $71.33 \mathrm{e}$ & $19.33 \mathrm{f}$ & $58.02 \mathrm{e}$ & $74.35 \mathrm{~d}$ & $2344.14 \mathrm{e}$ \\
$\mathrm{TP}$ & $153.33 \mathrm{a}$ & $118.66 \mathrm{a}$ & $66.00 \mathrm{a}$ & $187.41 \mathrm{a}$ & $91.65 \mathrm{a}$ & $7571.36 \mathrm{a}$ \\
$\mathrm{R}_{4}$ & $98.53 \mathrm{bc}$ & $105.66 \mathrm{bc}$ & $47.00 \mathrm{c}$ & $127.06 \mathrm{c}$ & $87.01 \mathrm{abc}$ & $5133.49 \mathrm{c}$ \\
$\mathrm{R}_{8}$ & $117.20 \mathrm{~b}$ & $112.33 \mathrm{ab}$ & $56.33 \mathrm{~b}$ & $164.76 \mathrm{~b}$ & $90.17 \mathrm{ab}$ & $6656.43 \mathrm{~b}$ \\
$\mathrm{~B}_{10}$ & $91.26 \mathrm{~cd}$ & $102.33 \mathrm{c}$ & $42.66 \mathrm{~d}$ & $107.44 \mathrm{~d}$ & $85.78 \mathrm{bc}$ & $4340.84 \mathrm{~d}$ \\
$\mathrm{~B}_{20}$ & $73.46 \mathrm{~d}$ & $93.66 \mathrm{~d}$ & $33.66 \mathrm{e}$ & $99.25 \mathrm{~d}$ & $82.96 \mathrm{c}$ & $4009.96 \mathrm{~d}$ \\
\hline LSD & 20.72 & 6.84 & 2.71 & 8.21 & 4.99 & 331.68 \\
\hline
\end{tabular}

Values are the means of 10 plants per replicate (from 3 replicate). Values followed by the same letter within a column are not significantly different at the $0.05 \%$ level of probability according to LSD test.

From the previous discussion, it could conclude that, TP treatment was the most efficient to ameliorate soil moisture and temperature under bean plants during winter. Rice straw mulch also reported a significant increase in crop yield and growth parameters. The two rates of bentonite incorporation were significantly produce high yield compared to control, but still less than that found under both TP and $\mathrm{R}_{8}$ treatments. So, the choice was exclusive between plastic mulch and rice straw mulch. With considering the environmental friendship of straw mulch and its effect on increasing soil organic matter, the most attractive choice could be provided using the straw mulch. Also, it was detected that, the highest crop yield obtained under summer conditions was responded to minimizing soil temperature fluctuation. On the other hand, the highest crop yield obtained under winter conditions was responded to the relative increasing in soil temperature. 


\section{Conclusion}

Application of clay mineral bentonite could increase soil water retention, consequently, increase soil field capacity, while soil $K s$ decreased. Mualem's model could be an important approach to overcome dipping drying front built up in wetted soil. Soil thermal conductivity increased, while soil temperature fluctuation was decreased (under summer conditions) compared to the control as responded to bentonite application. From view point of plant growth, crop yield, economic and environmental friendly, it is recommended to use rice straw as soil surface mulch for both summer and winter seasons. It was detected that, the highest growth and crop yield in summer season responded to minimum soil temperature fluctuation. On the other hand, the same parameters in winter season responded to the relative increase in soil temperature.

\section{References}

Abdel-Nasser, G.; Al-Omran, A.M.; Falatah, A.M; Sheta, A.S. and Al-Harbi, A.R. (2007) Impact of natural conditioners on water retention, infiltration and evaporation characteristics of sandy soil. Journal of Applied Sciences 7(13), 1699-1708.

Abu-Hamdeh, N.H. (2003) Thermal properties of soils as affected by density and water content. Bio systems Engineering, 86 (1), 97-102.

Ali, K.M. (2011) A study of some methods of waste management of rice through its impact on soil physical properties, N, P and K contents in maize yield and water use efficiency under different tillage systems. Australian J. of Basic and Applied Sci., 5 (5), 1017-1034.

Allen, R.G.; Pereira, L.S.; Raes, D. and Smith, M. (1998) Crop Evapotranspiration. Guidelines for computing crop water requirements. Paper 56. FAO Rome.

Bristow, K.L. (1988) The role of mulch and its architecture in modifying soil temperature. Aust. J. Soil Res. 26, 269-280.

Carsel, R.F., and Parrish, R.S., (1988) Developing joint probability distributions of soil water retention characteristics. Water Resour. Res. 24, 755-769.

Carter, M.R. (1993) Soil Sampling and Methods of Analysis. Canadian Soc. Soil Sci. Lewis Pub. Boca Raton, FL., pp: 823.

Croker, J., Poss, R., Hartmann, C. and Bhutho, S. (2004) Effects of recycled bentonite addition on soil properties, plant growth and nutrient uptake in tropical sandy soil. Plant and Soil, 267.

Dahiya, R.; Ingwersen, J. and Streck, T. (2007) The effect of mulching and tillage on water and temperature regimes of loess soil: Experimental findings and modeling. Soil Till. Res. 96, 52-63. 
Farouki, O.T. (1966) Physical properties of granular materials with reference to thermal resistivity. Highway Research Record, no. 128, p. 25-44.

Geiger, R. (1959) The Climate Near the Ground. $3^{\text {rd }}$ ed. Harvard University press, Cambridge, Massachusetts. U.S.A.

Klepper, B. (1987) Root growth and temperature. Root Develop. Funct. 103, 200-205.

Klute, A. (1986) Ed. Methods of Soil Analysis. Part 1 Physical and Mineralogical Methods, SSSA INCS., Madison, Wisconsin USA.

Lal, R. (1974) Soil temperature, soil moisture and maize yield from mulched and unmulched tropical soils. Plant Soil, 40, 129-143.

Lee, H.C., (1997) Organic and inorganic aspects of fertiliser use strategies in cereals. Aspects Appl. Biol. 50, 95-101.

Li, Z.G.; Zhang, R.H.; Wang, X.J.; Wang, J.P.; Zhang, C.P. and Tian, C.Y. (2011) Carbon dioxide fluxes and concentrations in a cotton field in northwestern China: Effects of plastic mulching and drip irrigation. Pedosphere. 21(2), 178-185.

Movahedi Naeni, S.A.R., Cook, H.F., (2000a) Influence of compost amendment on soil water and evaporation. Commun. Soil Sci. Plant Anal. 31 (19/20), 3147-3161.

Mualem, Y., (1976) A new model for predicting the hydraulic conductivity of unsaturated porous media. Water Resour. Res. 12, 513-522.

Parkinson, R.J.; Fuller, M.P. and Groenhof, A.C. (1999) An evaluation of green waste compost for the production of forage maize (Zea mays L.). Compost Sci. Util. 17 (1), 72-80.

Payne, W.A. (1987) Water balance of sandy soils of Niger, West Africa. MS thesis. Texas A\&M University, College Station.

Ramakrishna, A., Tam, H.M., Wani, S.P. and Long, T.D. (2006) Effect of mulch on soil temperature, moisture and yield of groundnut in North Vietnam. Field Crops Res. 95, 115-125.

Sarkar, S. (2005) Evapotranspiration and yield response of wheat to irrigation frequencies and fertilizer levels. J. Indian Soc. Soil Sci. 53, 54-59.

Sarkar, S. and Rana, S.K. (1999) Role of tillage on productivity and water use pattern of rice-wheat cropping system. J Indian Soil Sci. 47, 532-534.

Sarkar, S. and Singh, S.R. (2007) Interactive effect of tillage depth and mulch on soil temperature, productivity and water use pattern of rainfed barley. Soil Till. Res. 92, 79-86.

Sarkar, S.; Paramanick, M. and Goswami, S.B. (2007) Soil temperature, water use and yield of yellow sarson (Brassica napus L. var. glauca) in relation to tillage intensity and mulch management under rainfed lowland ecosystem in eastern India. Soil Till. Res. 93, 94-101.

Egypt. J. Soil Sci. 56, No. 1 (2016) 
Sellers, G.; McRae, S.G. and Cook, H.F. (2001) Oilseed rape and bean production potential on amended former landfill site restored with London clay. Land Degrad. Dev. 12, 487-504.

Sheta, A.S.; Al-Omran, A.M. and Falatah, A.M. (2006) Effect of clay deposits on physicochemical and intermittent evaporation characteristics of torripsamment. Arid Land Research and Management, 20: 295-307.

Sharma, P.K., Verma, T.S., Bhushan, L. (1997) Effect of depth of root-zone on growth, yield and nutrient uptake of rice. Oryza 34, 234-237.

Shinners, K.J.; Nelson, W.S. and Wang, R. (1993) Effects of residue-free band width on soil temperature and water content. Trans. ASAE 37, 39-49.

Van Genuchten, M. Th. (1980) A closed-form equation for predicting the hydraulic conductivity of unsaturated soils. Soil Sci. Soc. Am. J. 44, 892-898.

Van Rooyen, M. and Winterkorn, H.F. (1959) Structural and textural influences on thermal conductivity of soils. Highway Research Board Proceedings vol. 39, p. 576621.

Wicks, G.A.; Crutchfield, D.A and Burnside, O.C. (1994) Influence of wheat straw mulch and metolachlor on corn growth and yield. Weed Sci., 42, 141-147.

Wu, C.L.; Chau, K.W. and Huang, J.S. (2007) Modelling coupled water and heat transport in a soil-mulch-plant-atmosphere continuum system. Applied Math. Modelling 31, 152-169

Yaghi, T.; Arslana, A. and Naoumb, F. (2013) Cucumber water use efficiency under plastic mulch and drip irrigation. Agricultural Water Management, 128, 149- 157.

إستجابة بعض خواص التربة وصفات النمو وإنتاج المحصول

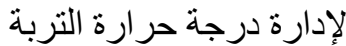

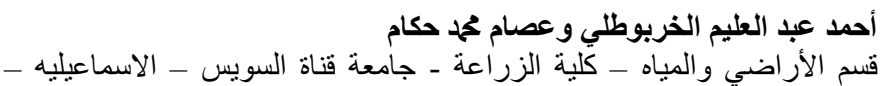

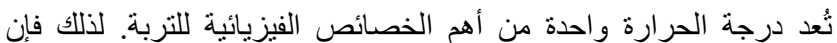

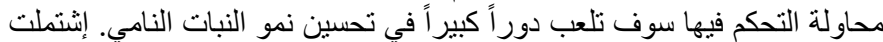

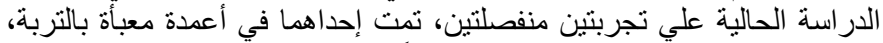

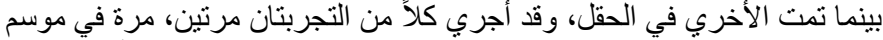

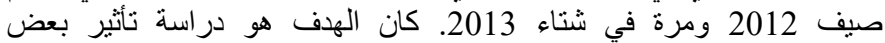

Egypt. J. Soil Sci. 56, No.1 (2016) 
المعاملات السطحية لتربة رملية القوام (تربة مزرعة كلية الزر اعة - بمحافظة

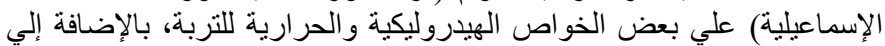

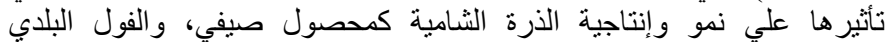

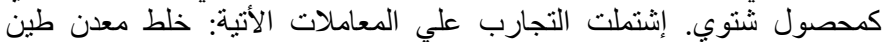

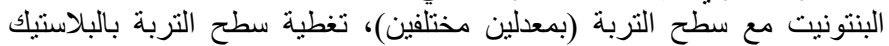

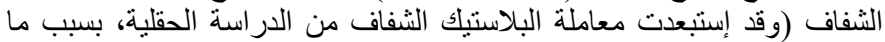

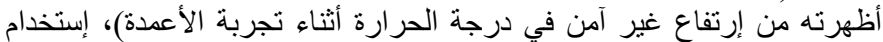

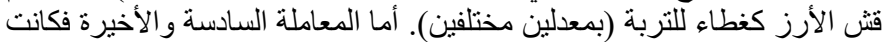

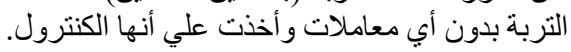

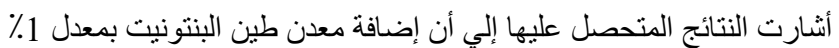

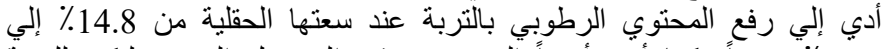

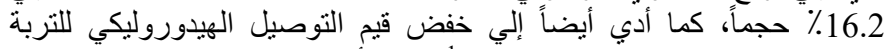

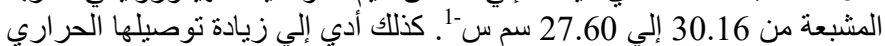

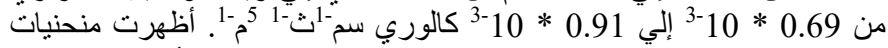
الحجز الرطوبي التي نتجت من تطبيق معادلة "فان جنشتن

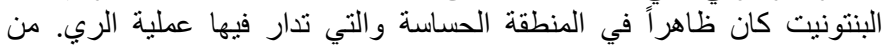

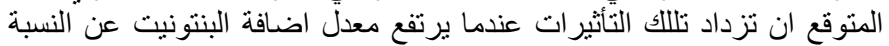

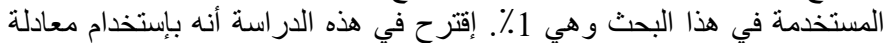

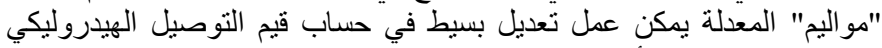

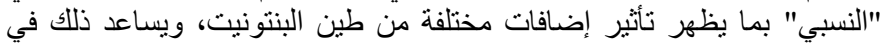

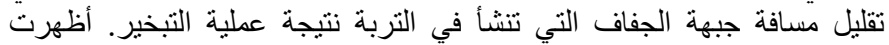

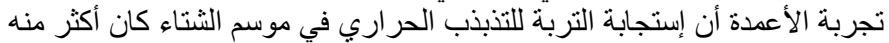

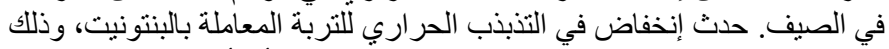

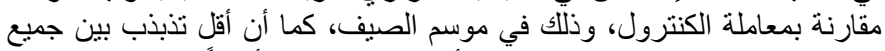

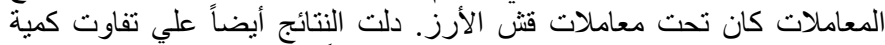

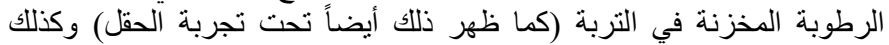

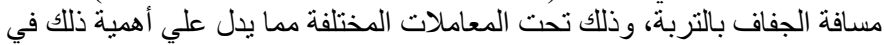

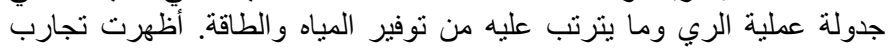

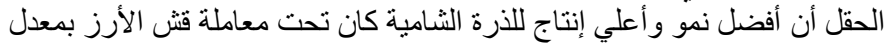

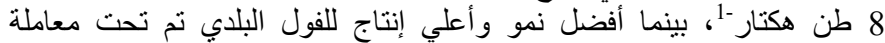

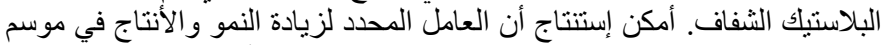

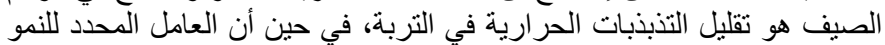

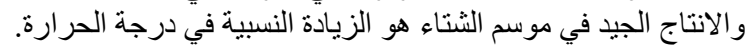

Egypt. J. Soil Sci. 56, No. 1 (2016) 